\begin{tabular}{l}
\hline OPEN O ACCESS Freely available online \\
http://www.banglajol.info/index.php/BJID/index \\
Perspective \\
Bangladesh Journal of Infectious Diseases \\
June 2020, Volume 7, Number 1, Page 33-37 \\
ISSN (Online) 2411-670X, ISSN (Print) 2411-4820 \\
DOI: https://doi.org/10.3329/bjid.v7i1.48675
\end{tabular}

\title{
Mental Health of School-Going Children during Existing Lockdown Situation Due to COVID-19 Pandemic in Bangladesh
}

\author{
Muhammad Anwar Hossain ${ }^{1}$, Sanjida Rahman ${ }^{2}$, Md Rezaul Karim ${ }^{3}$
}

${ }^{1}$ Tutor, Inspiration Academy, Dhaka, Bangladesh; ${ }^{2}$ Tutor, Pledge Harbor International School, Dhaka, Bangladesh; ${ }^{3}$ PhD Candidate, Institute of Nutrition and Food Science, University of Dhaka, Dhaka, Bangladesh \& Assistant Professor of Neurology and Principal Investigator, Institute of Neuroscience, Hubei University of Medicine, Shiyan, China

[Received: 17 October 2019; Accepted: 12 April 2020; Published: 1 June 2020]

\begin{abstract}
During this epidemic of COVID-19, children are in need of much concentration and profound love of the senior family members. Although the measures taken by the organizations are necessary to prevent the spread of the novel coronavirus, they may be causing widespread mental health issues, including depression and loneliness. Therefore, it is imperative that parents have to spend the lion-share of time with children while listening to them cordially. Parents can participate in sports with them to help them stay fit so that they can enjoy commemorating moments. However, in this additional time, the parents can also make them habituated to practice the rules of health, so does social distancing. [Bangladesh Journal of Infectious Diseases, June 2020;7(1):33-37]

Keywords: mental health; COVID-19; school-going children; lockdown

Correspondence: Dr. Md Rezaul Karim, MBBS, MD, MRCPS; PhD candidate, Institute of Nutrition and Food Science, University of Dhaka, Dhaka-1000, Bangladesh; Tel: +8801777093811; Email: dr_mdrezaulkarim@ hotmail.com

Conflict of interest: Authors declare that there is no conflict of interests.

Funding agency: The study was not funded by any authority.

Contribution to authors: Muhammad Anwar Hossain and Sanjida Rahman involved in protocol preparation, data collection and literature search up to manuscript writing. Md Rezaul Karim involved in literature search, preparation and revision of this manuscript.

How to cite this article: Hossain MA, Rahman S, Karim MR. Mental Health of School-Going Children during Existing Lockdown Situation Due to COVID-19 Pandemic in Bangladesh. Bangladesh J Infect Dis 2020;7(1):33-37

Copyright: (02020. Hossain et al. Published by Bangladesh Journal of Infectious Diseases. This article is published under the Creative Commons CC BY-NC License (https://creativecommons.org/licenses/by-nc/4.0/). This license permits use, distribution and reproduction in any medium, provided the original work is properly cited, and is not used for commercial purposes.
\end{abstract}

\section{Introduction}

During the era of fantastic scientific discovery, the introduction of various sophisticated technologies, and the rapid globalization process, the universe has been encountering an unprecedented natural obstruction without having any forecasts or precautions. It is a fact that the most potent and wellprotected countries are the most frightening, pathetic victims because of a sudden pandemic outbreak of coronavirus disease 2019 (COVID-19), a respiratory illness caused by the severe acute respiratory syndrome coronavirus 2 (SARS-CoV-2) ruling the world freely ${ }^{1-2}$. All the accumulated Weapons of 
Mass Destruction (WMD) seems useless in time of necessary disappointing the human beings. All reliable surveillance, safeguards, and defense became fragile and ridiculously the superb revolution of technology, well-equipped laboratories failed ultimately in combating or fighting against a micro virus. The medical technology, medicines changed characteristics dramatically to work to stand by the COVID-19 victims or cure them rapidly; instead, the tiny virus puzzles the health activists, physicians while changing its behavior now and then. Industries, aviation, aggression, oppression turned as alien within a blink. It seems to be the most powerful turned into the most powerless. The law of evolution promises the survival of the fittest. The greatest challenge faced by the world now is surviving the pandemic, not just with excellent physical health but with blooming mental fitness. No matter what comes tomorrow, our young survivors will know to fear the virus until we find a remedy. The global economy is witnessing a sudden fall down, and dominating countries locked down themselves without challenging the COVID-19 ${ }^{3-4}$. While we look at the bigger picture, the global economy, and the closed borders, we miss out on the permanent impact on young learners. In this review, we have described the real scenario of the mental health of school-going children of Bangladesh due to the pandemic of COVID-19 with some statements of child specialists, psychiatrists, psychological point of view and expertise.

\section{Lockdown Situation due to COVID-19 Pandemic}

The people all around the world surrendered themselves to the COVID-19, resulting in an indefinite shut down of educational institutes ${ }^{5}$. Like any other nation, Bangladesh's first step in fighting the pandemic was to announce the closure of schools indefinitely. For a while, what seemed to be in the spirit of a vacation, an extended holiday soon turned out to be a bag of uncertainty. The parents of the children are now in a total dilemma, whether they can send the children back to school anymore. The struggles of people of all walks cannot be exaggerated. Thousands of businesses, countless little or mediocre entrepreneurs, are in perilous havoc as they cannot figure out the compensations right away, let alone the tribulations of underprivileged people floating around the globe. Patients tested COVID-19 are taken away, and the victims' funeral is being done without showing their family members. Visiting neighbors, relatives, friends, markets, amusement parks are strictly forbidden as all are shut for an indefinite period, mainly to save the rest of the people currently under threat. People keep them away from each other and avoid shaking hands, fearing the possible spread of SARS-CoV-2. People now are in between devils and the deep sea. This pandemic situation fell the children into a serious contemplation, paradox, labyrinth. Moreover, the solitary environment, isolated atmosphere, death news, procrastination of lockdown is helping beef up the level of frustration in the soft mind of children, which is detrimental to their mental health. In Bangladesh, the presence of COVID-19 has been detected on March 8, 2020, officially. From that day until, the total number of tested positive people is more than 25000 , and the death toll is 370 . However, the pandemic situation is prevailing all over the world, including Bangladesh. Children in Bangladesh are in a severe mental agony on account of COVID-19, especially after having a surprise notice of closure of schools, coming across the prohibition of mingling with friends, teachers, favorite close door playmates, which drove them drastically to be flabbergasted ${ }^{6-7}$.

\section{Closures of Schools during Lockdown Situation}

It goes without debate that most children tend to be fun-loving, perform whimsically whatever they yearn to accomplish. Spacious premises of schools provide them with an opportunity to play innumerable sports, occupy with peers, classmates in a cozy atmosphere (Figure 1). Obesity of children lessens, which stimulates them to be refreshed and proactive in the area where they want to focus. They cannot apprehend when time goes, or the time of school is over. But this unanticipated COVID-19 perished all the frolic of their daily life, which frenzied them thoroughly ${ }^{8}$. The common errantry bolted precipitately without hypothesizing anything else. All the pernicious tidings associated with different channels made them squandered. While many private institutions have moved to remote learning methodologies, many schools around the nation have closed without further announcements. Students and parents of the latter category have limited or zero access to technology and are not equipped for an online classroom. These students are left to fight their own battles, prepare themselves with limited tools, and in most cases, no one to guide them. Many of them will inevitably drop out of school, mainly to support their home while their parents end up being without a source of income due to the falling economy. We have all cribbed about our schools in our days. The heavy bags, the extensive homework, the grueling tests, and the angry teacher have always made us pray for the day when school will be over once and for all. However, the same blokes look back on to our school days as the most memorable and colorful days of our lives. Unless the present scenario changes, which doesn't 
seem to be an up-and-coming prospect, we are going to have a generation with memories of school that means the same as the screen on their electronic devices. Due to the closures of schools, students are missing out on important life lessons in the form of a set of discipline, routine, and daily structure that is necessary for the mental growth of a child ${ }^{9}$. Children learn from watching adults, and since they will often be at home together now, they will observe not only what the adults in the home say but also how they implement structure, ensure consistency and deal with their own emotions. Students who are accustomed to going to school and mingling with friends every day will be the major victims of mental health issues because they are confined at their homes at the ripe age of learning social skills of their lives ${ }^{10}$. For many, the home is not a happy place, where there is a lingering threat of an unhappy and dysfunctional household. For them, their school, the safe-haven, is no longer a place where they can be happy and be with friends.

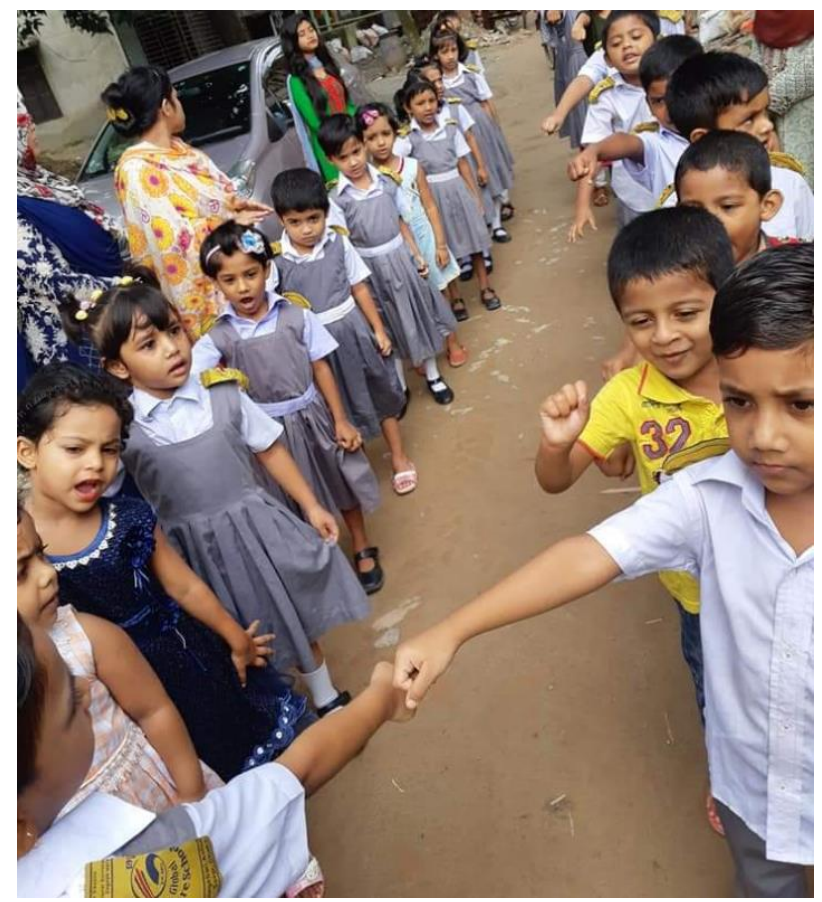

Figure I: School-going children getting ready for school activities in Bangladesh

\section{Online Remote Learning during Lockdown Situation}

A handful of school goers in Bangladesh have shifted to online remote learning, where the teachers are looking for various tools and mediums to keep the learning curve on the rise. Rather than a daily commute to school, the school has now come to their bedrooms. This poses a different type of threat to mental health for many. The small glimpse into their private space may share stories that they little want their classmates to know. This may range from the exposure of a lower-income household to fighting parents ${ }^{11-12}$. It poses an immense threat to the health of the youngsters as they have a status to maintain in front of their peers. It is, however, not all dark. Many enjoy the opportunity to show off their IT skills. Those who were always told off at home for poor academic results due to playing games and always being on their devices suddenly finds themselves at the top of the class. They are better able to find themselves around the screen and quickly jump from one tab to another.

\section{Mental Health of School-Going Children during Lockdown Situation}

With more than 25,000 COVID-19 positive cases in the country and numbers rising daily, it does not seem possible that schools will return to normal soon. Whenever they do return to normal functioning, there will be a serious mark left on the little minds. It depends not only on the teachers but also on the parents to ensure that the children adapt to the new normalcy the world is heading. Adults need to set an example of social distancing and healthy living to make the transit easier and less hampering for the children ${ }^{13-14}$. If anything, COVID19 has taught us, that life as we know now, may change at any moment. We are at the brink of an evolution, where wireless technology is proving to be a boon. In the name of this lockdown staring at the pandemic's face, we are teaching our children essential life skills. Those who learn and adapt are the fittest and will be the survivors.

Needless to say, that the flabby mind of school-going children in Bangladesh turned lugubrious after falling in a companionless predicament, which is fortuitous to them. The repugnant and skeptical, abnormal ambiance prevailing elsewhere of the globe, including Bangladesh as well as respective parents at home, pulled them to be comparatively panic-stricken. Once the parents used to go to an office, adjacent places, visit businesses, conduct meeting, attend seminars held whether at home or abroad or abroad tour are now incarcerated at home believing them becoming untrustworthy which directly affect the touchy mentality of children of all strata over here. Regular injudicious activities with friends at school premises and local playground broke off triggering the hallucination of children depriving them of all facilities which severely hit the light-hearted children ${ }^{15}$. Again, changing the recurring penchant in the natural lifestyle pressurized them to be more intrusive to find out painstaking vindication and finally to fend off the 
gamble, which explicitly damages the mental tranquility of children.

Moreover, the mental agony of children accelerates whenever they come across the ambiguity in the face of parents who have been chasing after the worst omen while facing financial impediments and an uncertain future towards them. Most importantly, the soporific sound like COVID-19, everlastingly hearing, listening coming from the polluted air chanting by media and orders compelled them to draw a melancholy photograph of coronavirus what it looks like, dangerously affect the sacrosanct mind of children which forced them to become sick and worried. Lastly, the disappointing news and misgivings about the coronavirus made them mentally upset, which is a considerably alarming symbol for the future change-makers ${ }^{16}$. There are several factors that critically and actively disturb the mental health of children during this sudden, the pandemic outbreak of COVID-19 (see Table 1). Several factors can help school-going children get rid of immense depression during the pandemic outbreak of COVID-19 (Table 2).

Table 1: Factors disturbing the mental health of children during the COVID-19 pandemic

\begin{tabular}{|l|l|}
\hline $\begin{array}{l}\text { Serial } \\
\text { No. }\end{array}$ & $\begin{array}{l}\text { Factors disturbing the mental health of } \\
\text { children }\end{array}$ \\
\hline 1 & $\begin{array}{l}\text { Social distancing and isolation for weeks, } \\
\text { months }\end{array}$ \\
\hline 2 & Fear of the unknown, stress \\
\hline 3 & $\begin{array}{l}\text { Having insufficient information or } \\
\text { explanation from respective guardians or } \\
\text { frontline health workers about COVID- } \\
19\end{array}$ \\
\hline 4 & $\begin{array}{l}\text { Increasing family feud in the outbreak of } \\
\text { COVID-19 }\end{array}$ \\
\hline 5 & $\begin{array}{l}\text { Having stressful disorder on account of } \\
\text { COVID-19 }\end{array}$ \\
\hline 6 & $\begin{array}{l}\text { Having a rapid change in sleep or eating } \\
\text { manner }\end{array}$ \\
\hline 7 & Deteriorating of chronic health problems \\
\hline 8 & Worsening of mental health states \\
\hline 9 & Lacking proper mentorship \\
\hline 10 & Avoidance of merriments \\
\hline 11 & $\begin{array}{l}\text { Having niggardly attention and } \\
\text { concentrations }\end{array}$ \\
\hline 12 & $\begin{array}{l}\text { Receiving news which is unbearable and } \\
\text { excruciating like the } \\
\text { bereavement }\end{array}$ \\
\hline 13 & $\begin{array}{l}\text { Having no probable guarantee of the } \\
\text { combating of COVID-19 }\end{array}$ \\
\hline
\end{tabular}

Table 2: Factors can help get rid of the depression of children during the COVID-19 pandemic

\begin{tabular}{|c|c|}
\hline $\begin{array}{l}\text { Serial } \\
\text { No. }\end{array}$ & $\begin{array}{l}\text { Factors can help get rid of the } \\
\text { depression of children }\end{array}$ \\
\hline 1 & $\begin{array}{l}\text { Making them understand that this } \\
\text { problem is transient }\end{array}$ \\
\hline 2 & Helping them wake up on regular time \\
\hline 3 & Encouraging them to do what they like \\
\hline 4 & $\begin{array}{l}\text { Avoidance of coercion in anything they } \\
\text { have apathy }\end{array}$ \\
\hline 5 & Spending more time with them \\
\hline 6 & Introducing fun-filled activities \\
\hline 7 & Making a nutrient diet chart \\
\hline 8 & $\begin{array}{l}\text { Assuring them of that lights are coming } \\
\text { soon after the darkness }\end{array}$ \\
\hline 9 & $\begin{array}{l}\text { Researching some positive videos to } \\
\text { offer the kids }\end{array}$ \\
\hline 10 & $\begin{array}{l}\text { Escalating empathy among the family } \\
\text { members }\end{array}$ \\
\hline 11 & $\begin{array}{l}\text { Making video calls to some friends or } \\
\text { relatives, they are fond of }\end{array}$ \\
\hline 12 & $\begin{array}{l}\text { Children react, in part, on what they see } \\
\text { from the adults around them. Whenever } \\
\text { COVID-19 is being dealt with calmness } \\
\text { and confidence, this provides the best } \\
\text { support for the children. Parents have to } \\
\text { be more lenient and reassuring to others } \\
\text { around children }\end{array}$ \\
\hline 13 & $\begin{array}{l}\text { Talking to them frankly about COVID- } \\
19\end{array}$ \\
\hline 14 & $\begin{array}{l}\text { Responding questions and share facts } \\
\text { about COVID- } 19 \text { in a way that children } \\
\text { can understand easily }\end{array}$ \\
\hline 15 & $\begin{array}{l}\text { Sharing own ideas how we parents deal } \\
\text { with stress to make them learn how to } \\
\text { cope up with changing environment }\end{array}$ \\
\hline 16 & $\begin{array}{l}\text { Limiting family's exposure to news } \\
\text { channels coverage of the event, } \\
\text { including social media. Children may } \\
\text { misinterpret what they hear and have } \\
\text { chances to be frightened about } \\
\text { something they do not understand }\end{array}$ \\
\hline 17 & $\begin{array}{l}\text { Being a role model, take breaks, get } \\
\text { plenty of sleep, exercise and eat well }\end{array}$ \\
\hline 18 & $\begin{array}{l}\text { Helping them to be more optimistic and } \\
\text { challenging }\end{array}$ \\
\hline 19 & $\begin{array}{l}\text { Taking E-therapy and E-counselling } \\
\text { services from the experts if required }\end{array}$ \\
\hline 20 & $\begin{array}{l}\text { Making them believe that children are } \\
\text { not prone to COVID - } 19\end{array}$ \\
\hline 21 & Being completely passionate to them \\
\hline
\end{tabular}




\section{Conclusion}

The more we become nature friendly, the better and sustainable dwelling place we can construct for the children. Researchers have already come into a consensus that this is a natural calamity. Nature started behaving abnormally and aggressively as we behaved crossly and unfriendly ways. It is a demanding global urge to minimize the competition of making weapons of mass destruction, which destroy the nation, and human civilization instead maximizes the protection program of nature to evade the potential future threats. It has been proved that human beings are responsible for the deterioration of the natural environment. Therefore, we have to come back to an umbrella platform with only one and echo that we will be upholding human civilization, which is more secure for innocent children without lust. We will be paying more heed to discover alternatives to conserve humanity without craving after the unnecessary, unhealthy competition to grab the power, to destroy countries standing some. The ultimate lesson of COVID-19 taught us that we are still helpless towards nature. Therefore, we should go green and go natural, and we also need to be friendly to children by dint of all noble intentions, activities, and planning.

\section{References}

1. Burki T. Outbreak of coronavirus disease 2019. The Lancet Infectious Diseases 2020;20(3):292-293

2. Atkinson B, Petersen E. SARS-Cov-2 shedding and infectivity. The Lancet 2020, 395(10233):1339-1340.

3. Baldwin R, Weder di Mauro B. Economics in the time of COVID-19. London, UK: CEPR Press, 2020
4. Maria N, Zaid A, Catrin S, Ahmed K, Ahmed AJ, Christos I, Maliha A, Riaz A. The socio-economic implications of the coronavirus pandemic (COVID-19): A review. International Journal of Surgery 2020;78:185-93

5. Kickbusch I, Leung GM, Bhutta ZA, Matsoso MP, Ihekwea zu C, Abbasi K. Covid-19: how a virus is turning the world upside down. BMJ 2020; 369:1336

6. Hossain I. The epidemiological characteristics of an outbreak of 2019 novel coronavirus diseases (COVID-19) in Bangladesh: A descriptive study. Journal of Medical Science and Clinical Research 2020;08(04).

7. World Health Organization. Bangladesh COVID-19 Situation Report No. 12. WHO World Health Organization 20 May 2020. https://www.who.int/docs/defaultsource/searo/bangladesh/covid-19-who-bangladesh-situationreports/who-ban-covid-19-update-1220200518.pdf?sfvrsn= bdf1a 9114

8. Mohamed M, Riadh M, Karolina EK. COVID-19: How the Quarantine could lead to the Depreobesity, Obesity Medicine, 2020, 100255.

9. Md Hasinur RK, Ahmed H. COVID-19 Outbreak Situations in Bangladesh: An Empirical Analysis. medRxiv 2020, 20068312.

10. Islam MT, Talukder AK, Siddiqui MN, Islam T. Tackling the Pandemic COVID-19: The Bangladesh Perspective. Preprints 2020, 2020040384.

11. Zafari NK, Distance Education for Rohingya Children during COVID 19 Emergency: Bangladesh Rohingya Response Perspectives; Challenges, Recommendations and Proximities. SSRN 2020, 3594676.

12. Mohiuddin A. A Pandemic Review of Covid-19 Situation in Bangladesh. The American Journal of Medical Sciences and Pharmaceutical Research, 2020;2(05):38-50.

13. Lenore M, Susan L. COVID-19, Risk, Fear, and Fall-out. Medical Anthropology 2020, E-pub: 26 Mar 2020.

14. Mohiuddin AK. Covid-19 Situation in Bangladesh. Preprints 2020, 2020050094.

15. Santu S. Covid-19 Negative Effects on Childhood Friendship"- An Analysis. Tathapi with ISSN 2320-0693 is an UGC CARE Journal 2020;19(8).

16. Avinash DS, Mohandas E, Afzal J. Psychological interventions during COVID-19: Challenges for low and middle income countries. Asian Journal of Psychiatry 2020;51:102128 